\title{
Psychobiological impairment in rats following late-onset protein restriction
}

\author{
ELIZABETH F. GORDON, M. RAY DENNY, and JENNY T. BOND \\ Michigan State University, East Lansing, Michigan 48824
}

\begin{abstract}
Mature rats were kept on protein-deficient diets to test the hypothesis that late-onset protein restriction results in deficits and to determine the feasibility of doing nutritionbehavior research with old naive animals. A 3\% low-protein (LP) group and a $24 \%$ adequateprotein (AP) pair-fed control were used. Body weights and plasma protein concentrations were lower and exploratory behavior and motor coordination were poorer for LP rats. Both groups preferred the $24 \%$ protein diet. LP rats habituated slower and failed to overcome an initial black preference on an oddity discrimination learning task. Nutrition-behavioral research with older rats is feasible, and late-onset protein restriction produces psychobiological deficits.
\end{abstract}

Psychobiological deficits related to protein deficiency have been demonstrated in animals put on restricted diets during the perinatal period (Cowley \& Griesel, 1964; Frankova, 1973; Randt \& Derby, 1973; Sobotka, Cook, \& Brodie, 1974). Various nutritional deficiences occur during adulthood and aging (Greger, 1977; Loeb \& Howell, 1970; Vinther-Paulsen, 1952; Whanger \& Busse, $1975)$, and protein is one of the limited nutrients (Barrows \& Roeder, 1977). There is a paucity of data on physical and behavioral effects of late-onset nutritional deprivation. The major objectives of the present study were to develop a protein-deficiency model using older animals and test the hypothesis that late-onset deprivation results in physical and behavioral deficits.

\section{METHOD}

\section{Subjects}

Twenty 200-day-old male Holtzman rats were placed in pairs for the purpose of pair feeding. One rat of each pair was randomly selected to be fed the $3 \%$ low-protein (LP) diet, and the other pair member was fed a $24 \%$ adequate-protein (AP) diet (Table 1). The diets were made isocaloric. LP animals were fed ad lib on Day 1 of the experiment. On the following day, pair-fed AP animals received the same amount eaten by their pair members in the previous 24-h period (Yang \& Mickelsen, 1972). This feeding procedure was continued throughout the 300 days of the study. Tap water was available ad lib for both groups, and the laboratory was on a 12-h photoperiod daily.

\section{Apparatus}

Testing equipment included (1) a plywood square open field with $6415-\mathrm{cm}$ squares enclosed by a 30-cm-high plywood wall, (2) a rotarod motor-coordination apparatus consisting of a sandpapered drum, $15 \mathrm{~cm}$ in diameter, which was attached to a motor that could be rotated at 12,20 , or $30 \mathrm{rpm}$, and (3) an oddity-discrimination apparatus with a startbox, choice area, and end chamber. Four removable boxes, two black (B) and two

This research was supported in part by NIMH Training Grant MH14622, Michigan Agricultural Exper. Station Jour. Art. No. 10,003. We thank Ellen Rolig for her technical assistance. Reprints may be obtained from the first author, Department of Psychology, Wayne State University, Detroit, Michigan 48202.
Table 1

Composition of Diets

\begin{tabular}{rlr}
\hline $\begin{array}{c}3 \% \\
\text { Protein }\end{array}$ & $\begin{array}{r}24 \% \\
\text { Protein }\end{array}$ \\
\hline 3.35 & Casein (90\% Protein) & 26.70 \\
.05 & Methionine & .40 \\
4.00 & Minerals (Bernhart-Tomarelli Salt Mixture) & 4.00 \\
.40 & Vitamins & .40 \\
.20 & Choline Chloride & .20 \\
5.00 & Fat (Mazola Corn Oil) & 5.00 \\
5.00 & Cellulose & 5.00 \\
82.00 & Glucose & 58.30 \\
\hline
\end{tabular}

Note-Values are given in grams. Columns total $100 \mathrm{~g}$.

white (W), were inserted three at a time into the end chamber in various combinations of left, right, and center (e.g., WBB, BWB, or WBW).

\section{Procedure}

Food intake and body weights were monitored throughout the study. Following 70 days of the feeding procedure, animals were etherized and a heparinized blood sample was taken by orbital sinus puncture. Plasma protein concentrations were determined, using the procedure described by Lowry, Rosebrough, Farr, and Randall (1951). Animals were kept under the experimental conditions for an additional 230 days, and testing was conducted.

\section{Testing}

Test 1: Exploratory behavior. The animals were approximately 320 days old at the time of testing and had been under the pair-feeding condition for 120 days. Each animal was placed in the corner of the open field and observed for $3 \mathrm{~min}$. The total number of squares entered was recorded.

Test 2: Food preference. The animals were approximately 330 days old and had been pair fed for 130 days. Two food cups, one containing the LP and the other the AP diet, were placed in each home cage and fastened to prevent movement. The cups were rotated from side to side to control for position bias. The amount eaten from each cup was recorded at the end of each 24-h period for a total of 4 days.

Test 3: Motor coordination. The animals were approximately 350 days old and had been pair fed for 150 days at the time of testing. Animals were tested according to the procedure described by Overmann (1977). Each subject was placed on the rotating drum. There were three practice trials, with the drum rotating at 
12,20 , and $30 \mathrm{rpm}$, and three test trials. The number of seconds that the animal remained on the drum during the test trials was recorded.

Test 4: Oddity-discrimination learning. Habituation was begun when the animals were 450 days old and had been pair fed for 250 days. Following 8 days of habituation, the test trial procedure was started. All animals were initially habituated to the apparatus following $6 \mathrm{~h}$ of water deprivation. Each animal was placed in the startbox and allowed to move about freely. Water artificially sweetened with saccharin was available in each endbox. This procedure was repeated daily until the animals were drinking within 3 min of being placed in the startbox. The animals then had 12 trials each day, and all combinations (WBW, WBB, WWB, BWB, BWW, and BBW) were randomly presented twice. The water reinforcement was available in the odd box only. When the animal entered the correct box, that door was lowered and drinking was allowed for $5 \mathrm{sec}$. A variable intertrial interval (ITI) was used. The acquisition criterion was 10 correct responses in 12 trials. The rate of habituation and the number of correct choices were recorded.

Data were analyzed using student's t test and ANOVA techniques. A minimum level of significance $(p \leqslant .05)$ was set prior to the start of the study and nondirectional tabled values were used.

\section{RESULTS}

The LP animals had significantly lower plasma protein concentrations, compared with the AP animals $[t(9)=2.85, p \leqslant .05]$. Body weights were significantly less for the LP group than for the AP group $[\mathrm{t}(9)=2.78$, $\mathrm{p} \leqslant .05]$. These differences continued for the duration of the study.

\section{Test 1: Exploratory Behavior}

Exploratory behavior as measured by the number of squares entered in the open field was significantly different between the LP and AP groups, in that the AP animals entered a greater number of squares than the LP animals (Table 2) $[\mathrm{F}(1,14)=5.01, \mathrm{p} \leqslant .05]$.

Table 2

Exploratory Behavior of Male Holtzman Rats in an Open Field

\begin{tabular}{cll}
\hline & \multicolumn{2}{l}{ Number of Squares Crossed } \\
\cline { 2 - 3 } Diet & Mean & SE \\
\hline AP Group & 88.86 & 9.00 \\
LP Group & 65.88 & $5.78^{*}$ \\
\hline
\end{tabular}

Note-Animals were 320 days of age at testing and had been on their respective diets for 120 days. * *Significantly less than the AP group ( $p \leqslant .05)$.

Table 3

Mean Number of Grams of Food Consumed by the LP and AP Animals When Offered Both the 3\% and 24\% Diets for 4 Consecutive Days

\begin{tabular}{|c|c|c|c|c|c|c|c|c|}
\hline \multirow{2}{*}{$\begin{array}{l}\text { Pro- } \\
\text { tein } \\
\end{array}$} & \multicolumn{2}{|c|}{ Day 1} & \multicolumn{2}{|c|}{ Day 2} & \multicolumn{2}{|c|}{ Day 3} & \multicolumn{2}{|c|}{ Day 4} \\
\hline & LP & AP & LP & AP & LP & $\mathrm{AP}$ & LP & AP \\
\hline $24 \%$ & 26.6 & 21.6 & 21.3 & 17.9 & 20.4 & 21.6 & 21.0 & 23.4 \\
\hline $3 \%$ & 6.2 & 12.4 & .4 & 4.9 & .9 & 5.4 & .9 & 4.3 \\
\hline
\end{tabular}

Table 4

Mean Number of Seconds That the LP and AP Animals Remained on the Rotarod Drum

\begin{tabular}{cccc}
\hline & \multicolumn{4}{c}{ Rotarod Speed (in Revolutions per Minute) } \\
\cline { 2 - 4 } Diet & 12 & 20 & 30 \\
\hline LP & 1.41 & 1.32 & .84 \\
AP & 2.12 & 1.78 & 1.43 \\
\hline
\end{tabular}

Table 5

Number of White End Boxes Entered by Male Holtzman Rats During Oddity-Discrimination Learning

\begin{tabular}{ccc} 
& \multicolumn{2}{c}{ Number of White End Boxes Entered } \\
\cline { 2 - 3 } Diet & Mean & SD \\
\hline AP Group & 46.6 & 9.18 \\
LP Group & 20.8 & $8.60^{*}$ \\
\hline
\end{tabular}

Note-Animals were 450 days old at the time of testing and had been on their respective diets for 250 days. Two of the LP group would not habituate to the learning apparatus and were not included in the statistical analysis. *Significantly fewer than the adequate-protein group $(p<.001)$.

\section{Test 2: Food Preference}

The LP animals $[t(7)=7.102, p \leqslant .001]$ and AP animals $[t(6)=2.77, p \leqslant .05]$ had a significant preference for the AP diet when both diets were offered simultaneously. LP rats ate less $3 \%$ diet than AP animals did throughout the 4 days (Table 3 ).

\section{Test 3: Motor Coordination}

A 2 by 3 diet by speed analysis of variance of the rotarod data revealed significantly poorer performance for the LP group by diet $[\mathrm{F}(1,13)=28.37, \mathrm{p} \leqslant .001]$ and speed $[\mathrm{F}(2,26)=44.24, \mathrm{p} \leqslant .001]$, with a significant interaction of diet and speed $[\mathrm{F}(2,26)=3.79$, $\mathrm{p} \leqslant .05]$ (Table 4).

\section{Test 4: Oddity-Discrimination Learning}

Two animals from the LP group would not habituate to the testing apparatus and were not included in the data analysis. There was a significant difference in the rate of habituation to the learning apparatus. All AP animals were habituated by the 3rd day, whereas all of the LP animals tested required an additional 5 days of habituation. Differences for the number of correct choices made were not significant; however, the AP group made fewer errors.

A strong preference for black endbox choice was noted for all animals during habituation. The LP group maintained this preference throughout testing, whereas the AP group overcame this initial preference, as evidenced by the latter group's entering a greater number of white endboxes. The black preference manifested by the LP group was significantly different from that of the AP group $[\mathrm{t}(8)=4.07, \mathrm{p} \leqslant .01]$ (Table 5). 


\section{DISCUSSION}

Findings from the present study support the hypothesis that protein restriction imposed during adulthood and aging results in physical and behavioral deficits in male Holtzman rats. Previous studies reporting impairment related to protein deficiency have been concerned with the effects during pre- and postnatal development (Cowley \& Griesel, 1964; Frankova, 1973; Randt \& Derby, 1973; Sobotka et al., 1974). This study extends the literature by demonstrating that protein deficiency can be induced using an older animal model, so that consequences can be evaluated on selected physical and behavioral parameters. The need for such a model is evident, since various nutritional deficiencies have been reported during adulthood and aging. Whanger and Busse (1975) stated that the majority of psychogeriatric patients admitted to their hospital were eating doubtfully adequate to grossly inadequate diets and that it is often difficult to determine if these dietary deficiencies cause the disorder or result from it. The results of the present study suggest that behavioral changes can occur subsequent to inadequate intake, at least for protein.

In the present study, there were physical and behavioral deficits for all parameters tested, regardless of the duration of the insult. Several comparisons can be made between the results of this study, which utilized older rats, and findings from previous investigations involving young protein-restricted animals. Decreased exploratory behavior, noted in the present study, was reported by Cowley and Griesel (1964), who found that the mean ambulation score was lower for LP animals than for controls. Peregoy, Zimmerman, and Strobel (1972) reported that previously protein-malnourished rhesus monkeys showed a marked preference for high-protein food. This preference was also found in these older protein-restricted rats; however, the latter were not renourished prior to testing, and the former were. While interpretation of this finding is difficult, it is apparent that food-preference tests for protein can be done using older laboratory rats. Learning deficits have been demonstrated in younger animals (Bush \& Leathwood, 1975; Giurintano, 1974). The protein-restricted animals in this study tended to make more errors than did those receiving the AP diet; however, neither group reached the learning criterion. The probable explanation is that the learning task was too difficult for both groups of older animals. Age appropriateness of learning tests needs to be considered in future studies of this nature.

Results from the learning procedure revealed that the LP rats showed a learning deficit, in that they failed to overcome an initial black color preference. This is of interest in that failure to explore specific areas of the testing apparatus based on color avoidance would prevent learning whether the task was simple or complex.

In summary, an animal model was developed using older rats. Behavioral deficits were found in previously well nourished animals fed an LP diet during adulthood and aging. Although these rats were tested on various parameters at different times during the nutritional insult, it would be possible to design a battery containing these tests to be administered at various times during deprivation to determine the possible differential effects related to duration of protein restriction. A model similar to the one used here could be used to test effects of lateonset dietary stress involving nutrients other than protein.

\section{REFERENCES}

Barrows, C. H., Jr., \& Roeder, L. M. Nutrition. In C. E. Finch \& L. Hayflick (Eds.), Handbook of the biology of aging. New York: Van Nostrand Reinhold, 1977.

Bush, N., \& Leathwood, P. D. Effect of different regimens of early malnutrition on behavioral development and adult avoidance learning in Swiss adult mice. British Journal of Nutrition, 1975, 33, 373-385.

Cowley, J. J., \& Griesel, R. C. Low-protein diet and emotionality in the albino rat. Journal of General Psychology, 1964, 104, 89-98.

Frankova, S. Effect of protein-calorie malnutrition on the development of social behavior in rats. Developmental Psychobiology, 1973, 6, 33-43.

Grunintano, S. L. Effects of protein-calorie deficiencies on the learning ability of the Wistar rat. Physiology \& Behavior, $1974,12,55-59$

Greger, J. L. Dietary intake and nutritional status in regard to zinc of institutionalized aged. Journal of Gerontology, 1977, $32,549-553$.

LoEB, M. B., \& Howeu, S. C. Adult stress and diet. Gerontologist, $1970,9,46-52$.

Lowry, O., Rosebrough, N., Farr, A., \& Randall, R. Protein measurement with the Folin-phenol reagent. Journal of Biological Chemistry, 1951, 193, 265-275.

Overmann, S. R. Behavioral effects of asymptomatic lead exposure during neonatal development in rats. Toxicology and Applied Pharmacology, 1977, 41, 459-471.

Peregoy, P. L., Zimmermann, R. R., \& Strobel, D. A. Protein preference in protein-malnourished monkeys. Perceptual and Motor Skills, 1972, 38, 495-503.

RANDT, C. T., \& DERBY, B. M. Behavioral and brain correlations in early life nutritional deprivation. Archives of Neurology, 1973, 28, 166-172.

SobotкA, T. J., Cook, M. P., \& Brodie, R. E. Neonatal malnutrition: neurochemical hormonal and behavioral manifestations. Brain Research, 1974, 65, 443-457.

Vinther-Paulsen, N. Senile anorexia. Geriatrics, 1952, 7, 274 279.

Whanger, A. D., \& Busse, E. W. Care in hospital. In J. G. Howells (Ed.), Modern perspectives in the psychiatry of old age. New York: Brunner/Mazel, 1975.

YANG, M. G., \& Mickelsen, O. Laboratory animals in nutritional research. East Lansing: Michigan State University Press, 1972.

(Received for publication June 19, 1981.) 